\title{
Advances in Trauma
}

Editor

LENA M. NAPOLITANO

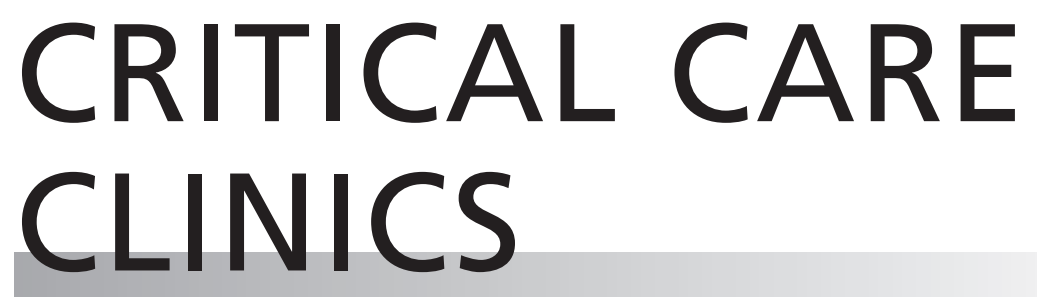

www.criticalcare.theclinics.com

Consulting Editor

JOHN A. KELLUM

January 2017 • Volume 33 - Number 1 